\title{
THE TRANSFORMATION OF THE EDUCATION SYSTEM DURING AND POST COVID-19
}

\author{
A TRANSFORMAÇÃO DO SISTEMA EDUCACIONAL DURANTE E PÓS-COVID-19
}

\author{
LA TRANSFORMACIÓN DEL SISTEMA EDUCATIVO DURANTE Y POSTAL COVID- \\ 19
}

\author{
Irina Grigorievna MALGANOVA ${ }^{1}$ \\ Diba Mazhitovna DOKHKILGOVA ${ }^{2}$ \\ Dzhamilya S. SARALINOVA ${ }^{3}$
}

\begin{abstract}
The article presents various approaches to the transformation of the modern education system, in the world, in the context of the COVID-19 pandemic. The authors suggest the following recommendations based on the research: a) the authorities should focus on developing strategies for rapid implementation of specific measures to support students and teachers throughout the forced break in the educational process; b) technical and organizational support is needed for the population of Russian regions due to various reasons, lack of necessary equipment, Internet connection and other online tools; c) protecting the rights of employees in secondary and higher education; d) ensuring social equality and inclusiveness, avoiding additional social stratification; e) protecting the personal information of students and teachers, preventing or minimizing risks arising from interaction in the virtual space, including cyberbullying. Also, the authors believe that the forced mass transition contributes to the fact that distance technologies are expected to boom in the near future, which has been discussed for several years. Experts in the field of educational policy predict the flourishing of e-learning in Russia. It is predicted that educational institutions will not return to the traditional format of education in full after the end of the quarantine.
\end{abstract}

KEYWORDS: Transformation. Higher education. COVID-19 pandemic. Social inequality. Social transformation. Information and communication technology. Geography. Space.

RESUMO: O artigo apresenta várias abordagens para a transformação do sistema educacional moderno, no mundo, no contexto da pandemia da COVID-19. Os autores sugerem as seguintes recomendações com base na pesquisa: a) as autoridades devem se concentrar no desenvolvimento de estratégias para a rápida implementação de medidas especificas para apoiar estudantes e professores durante toda a pausa forçada no processo educacional; b) o apoio técnico e organizacional é necessário para a população das regiões

\footnotetext{
${ }^{1}$ Kazan Federal University (KPFU), Kazan - Russia. Assistant Professor of the Department of Geography and Cartography, Institute of Economics, Management and Finance. Candidate of Sciences. ORCID: https://orcid.org/0000-0002-7313-9404. E-mail: irigrimmm@gmail.com

${ }^{2}$ Chechen State University (CHESU), Grozny - Chechen Republic - Russia. Assistant Professor of the Regional Economic Management Department. Candidate of Sciences. ORCID: https://orcid.org/0000-0001-9472-5309. Email: dibagrozny@mail.ru

${ }^{3}$ Chechen State University (CHESU), Grozny - Chechen Republic - Russia. Assistant Professor of the Regional Economic Management Department. Candidate of Sciences. ORCID: https://orcid.org/0000-0001-7997-4120. Email: puma-i@mail.ru
} 
russas por vários motivos, falta de equipamento necessário, de conexão à Internet e outras ferramentas on-line; c) proteger os direitos dos funcionários do ensino médio e superior; d) assegurar a igualdade social e a inclusão, evitando estratificação social adicional; e) proteger as informações pessoais dos estudantes e professores, prevenindo ou minimizando os riscos decorrentes da interação no espaço virtual, incluindo o cyberbullying. Os autores também acreditam que a transição forçada de massa contribui para o fato de que se espera que as tecnologias a distância floresçam no futuro próximo, o que vem sendo discutido há vários anos. Especialistas na área de política educacional preveem o florescimento do elearning na Rússia. Prevê-se que as instituições educacionais não retornarão ao formato tradicional de educação em sua totalidade após o final da quarentena.

PALAVRAS-CHAVE: Transformação. Ensino superior. Pandemia da COVID-19. Desigualdade social. Transformação social. Tecnologia da informação e comunicação. Geografia. Espaço.

RESUMEN: El artículo presenta varios enfoques para la transformación del sistema educativo moderno en el mundo en el contexto de la pandemia COVID-19. Los autores sugieren las siguientes recomendaciones basadas en la investigación: a) las autoridades deben enfocarse en desarrollar estrategias para la rápida implementación de medidas específicas para apoyar a estudiantes y docentes durante la pausa forzada en el proceso educativo; b) se necesita apoyo técnico y organizativo para la población de las regiones rusas debido a varias razones que no cuentan con el equipo necesario, conexión a Internet y otras herramientas en línea; c) proteger los derechos de los empleados en la educación secundaria y superior; d) asegurar la igualdad y la inclusión social, evitando una estratificación social adicional; e) proteger la información personal de alumnos y profesores, previniendo o minimizando los riesgos derivados de la interacción en el espacio virtual, incluido el ciberacoso. Además, los autores creen que la transición masiva forzada contribuye al hecho de que se espera que las tecnologías a distancia aumenten en un futuro próximo, lo que se ha debatido durante varios años. Los expertos en el campo de la política educativa predicen el florecimiento del e-learning en Rusia. Se prevé que las instituciones educativas no volverán al formato tradicional de educación en su totalidad después del final de la cuarentena.

PALABRAS CLAVE: Transformación. Enseñanza superior. Pandemia de COVID-19. Desigualdad social. Transformación social. Tecnología de la información y la comunicación. Geografia. Espacio.

\section{Introduction}

There are more than 1.57 billion people worldwide. students (more than $91.3 \%$ ) are forced to learn a new format of training today. Educational institutions in 191 countries have switched to distance learning in response to the pandemic (BOZKURT; SHARMA, 2020). Emergency remote teaching in a time of global crisis due to CoronaVirus pandemic. Asian Journal of Distance Education, v. 15, n. 1, i-vi. but only 53 States have specialized educational platforms. Others use various commercial and non-commercial systems. In 
addition, educational content is transmitted via TV and radio channels (WAHYONO; HUSAMAH; BUDI, 2020). In Russia, the Russian e-school educational platform is defined as a national one.it should be clarified here that, as in other countries, school classes are held not only on its basis.

The education system was on the front line with a large number of students: about 1.5 million school teachers and University teachers, as well as 16 million schoolchildren and 7 million students ${ }^{4}$.

\section{Materials and methods}

According to this research conducted in Russia at the stage of transferring training to distance learning at the end of March 2020, the majority of Russian secondary and higher school teachers in the country declare that the education system itself is not ready to transfer classes to a distance (online) format. The study was conducted among teachers of Russian institutions of General and higher education, whose opinions on the readiness of the educational system to transition to distance education are presented below (fig. 1,2).

Figure 1 - School teachers opinion working in Russian institutions of general education

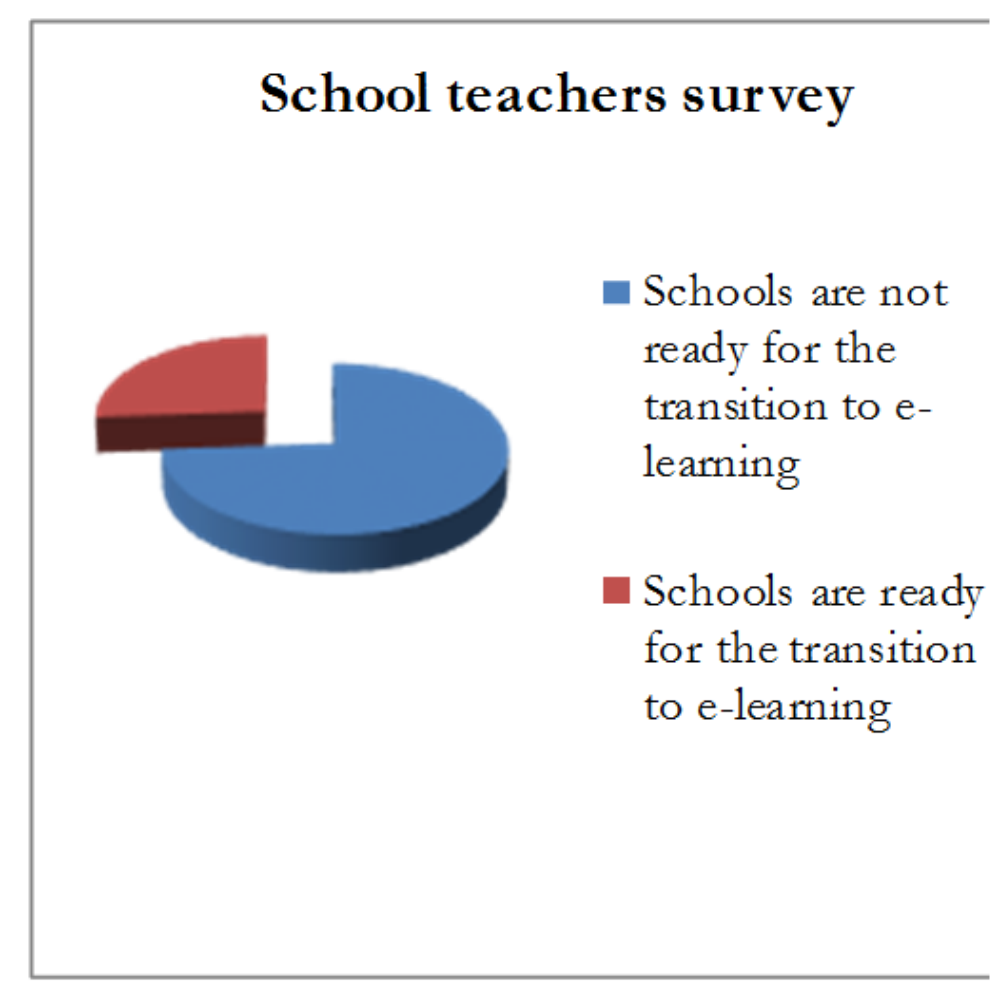

Source: Prepared by the authors

${ }^{4}$ Available: http://www.ng.ru/economics/2020-04-07/1_7837_education.html. Access: 10 dec. 2020. 
Figure 2 - University teachers opinion working in Russian higher education institutions

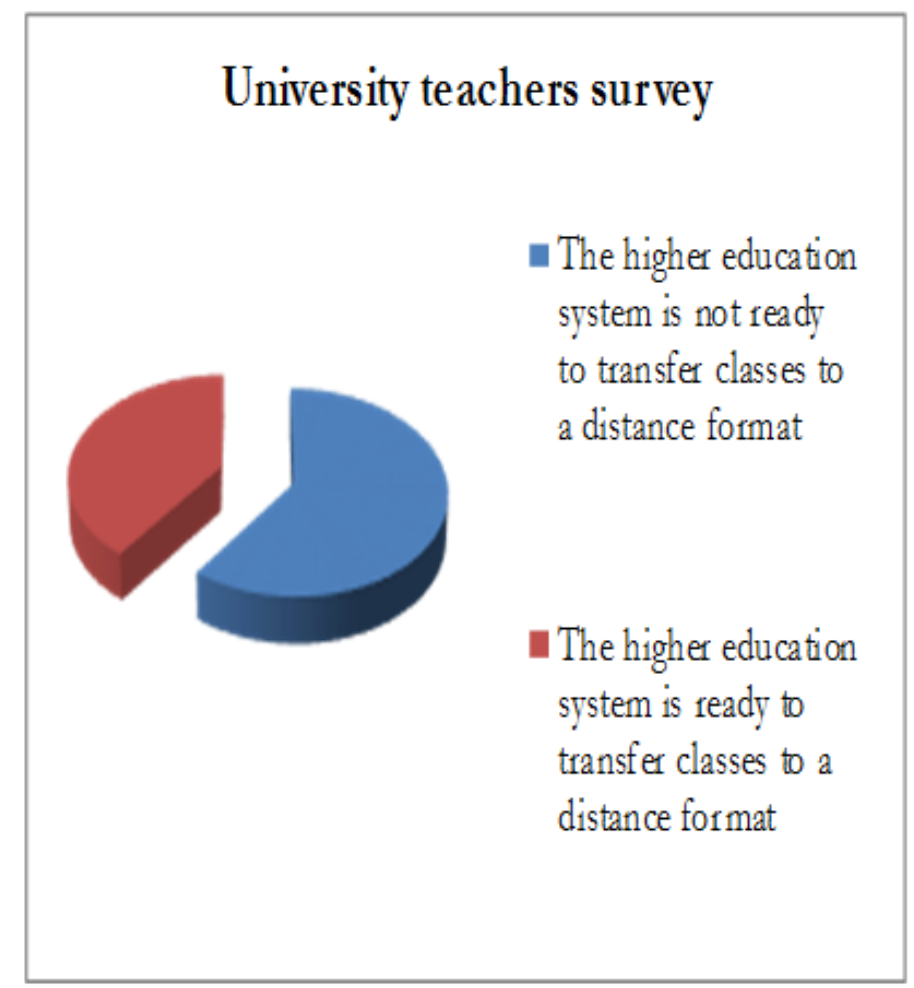

Source: Prepared by the authors

According to the results of the survey, two-thirds of Russian school teachers $(68 \%)$ believe that the school system is not ready to transform into distance learning. $24 \%$ of people believe that schools are ready for the transition. Among University teachers, the share of more optimistic assessments is higher: a third (35\%) believe that the higher education system is ready to transfer classes to a remote format, while $53 \%$ hold the opposite opinion.

At the same time, the assessment of their own methodological readiness to conduct classes in a distance format among school teachers and University teachers is about the same: the majority assess it satisfactorily (55\%). The problem of lack of skills and knowledge for the transition to distance learning was also voiced. At the same time, higher school teachers are slightly more optimistic than school teachers (the difference is $7-8 \%$ ). The level of readiness of both, according to their own words, is about the same $(55 \%)$.

The main technical problems are the following: lack of proper technical equipment of their organizations. The majority- $61 \%$ - rated it a "top three", only $15 \%$ indicated that their organization is equipped "very well".

Problems with education transformation are also reported in the Russian regions. For example, in Kazan city (Tatarstan Republic), out of 100 thousand students, due to the lack of necessary gadgets, 7 thousand students could not switch to the distance learning format.

RPGE- Revista on line de Política e Gestão Educacional, Araraquara, v. 25, n. esp. 1, p. 589-599, mar. $2021 . \quad$ e-ISSN:1519-9029 DOI: https://doi.org/10.22633/rpge.v25iesp.1.14999 
The transition in the education system was particularly difficult in the natural Sciences, including earth sciences related to space technologies. On the other hand, Kazan federal university has a positive experience in developing the project of the e-learning course "Geography Lessons from Space", which was developed by researchers of The Space Technologies in Territorial development Laboratory.

In the Chechen Republic, the weak Internet signal has also become a serious problem due to the mountainous terrain of the region ${ }^{5}$, and this is only a partial reflection of the overall situation in the country.

It is assumed that the way out of this situation will be to train them using messengers, direct telephone communication or individual consultations ${ }^{6}$. There is a threat of additional social stratification.

This situation is natural, since according to Rosstat, in 2018, there were an average of 52 personal computers, 81 laptops or tablets, and 136 smartphones per 100 households in cities. In the village, there were 43 PCs, 54 laptops or tablets, and 107 smartphones per 100 households. At the same time, the poorest group of the population had only 41 computers, 47 laptops or tablets, and 107 smartphones per hundred households ${ }^{7}$.

Due to the lack of experience and skills in the field of digital technologies, as well as due to the insufficient level of digital literacy, a significant part of the population of the Russian Federation was not prepared to work remotely under quarantine. In fairness, it should be noted that the topic of preparing teachers for the online format is critical not only in Russia. In particular, according to the research company Bay View Analytics, 1.5 million teachers in the United States and $70 \%$ of them have never conducted classes in a virtual space $^{8}$.

the experience of the Chinese education system is very interesting, where only a day in 1150 institutions of higher education organized a system for evaluating the work of teachers and introduced 24,000 online courses, which allowed the government to develop a recommendation for the management and support of the education system. One of the main requirements was to maintain the level of quality of education and the volume of courses studied in the traditional form of education 9 .

${ }^{5}$ Available: www.checheninfo.ru. Access: 10 dec. 2020.

${ }^{6}$ Available: http://www.ng.ru. Access: 10 dec. 2020.

${ }^{7}$ Available: https://nafi.ru. Access: 10 dec. 2020.

${ }^{8}$ Available: http://www.ng.ru. Access: 10 dec. 2020.

${ }^{9}$ Available: https://ioe.hse.ru/news/350395636.html. Access: 10 dec. 2020. 
Taking into account the accumulated world experience, today it is necessary to focus on assessing the risks and prospects of implementing the educational process in Russian universities in the conditions of forced transition to distance forms.

\section{Results and discussion}

The concept of e-learning is new for both students and teachers. Taking into account resources and capabilities, the country is currently paying more attention to the fight against the pandemic situation, and we hope that training solutions will develop in the near future. The suspension of full-time training took everyone by surprise, but in a very short period of time, solutions with the functionality of the Internet and mobile communications are being developed.

We could say that the crisis acts as an incentive for the development of distance learning. The crisis also forces us to pay more attention to the practical implementation of digital literacy. This crisis does reveal many points for thinking about how to effectively use ICTs in training and education.

Several important aspects should be noted:

\section{Preparedness of the population.}

A) the Readiness of the student.

The level of readiness of the population to switch to distance learning is quite low.

Students demonstrate a fairly high adaptability to the new learning format, however, there are limitations associated with inequality. Many will not have access to the telecommunications tools needed to adapt to this new environment.

Unequal access to digital equipment depends on age groups, areas of residence, and socio-economic status.

Poor quality of communication services is also an obstacle. Remote provincial regions, in many cases mountainous, face limited access to ICT services.

It is important to understand how students will process the learning material at home, what abilities they have, the types of devices, the type of Internet (paid or free access, the cost of the Internet). The problem of high cost of telecommunications services will certainly come to the fore.

Many pupil, especially children in primary school, are not yet fully proficient in information technology and need help from their elders 
A serious problem is the lack of self-organization. If students are surrounded by a powerful control system - from their parents to a notification system-then students have to organize themselves at home, and this is not always successful. Parents are responsible for teaching children. Parents, in any case, most of them now have the additional responsibility of educating their children at home. If a family has several children of school age, then parents will have to devote almost all their time to their children's studies, which is fraught with economic costs.

It is necessary to consider the negative consequences for physical health, changes in the development of the brain and psyche of students.

The development of scoliosis, deterioration of vision, hearing from the use of headphones, etc. ${ }^{10}$, is not a complete list of pathological changes in health due to distance learning. Children's frequent use of digital technologies, dependence on them, and immersion in virtual space provoke dangerous changes in brain development and lead to "digital dementia"11. The perception of information in children becomes superficial, such processes have led to the appearance of the expression "surf" (SPITZER, 2014). The results of the OECD research presented in the report "Students and new technologies" are indicative. The report concludes with the following: "On average, the highest level of use (of information technology) in OECD countries is associated with significantly weaker results" ${ }^{12}$. The results show that more effective educational systems are located in countries where students are least "connected" to ICTs.

As the authors of the book "the Catastrophe of the digital school. In defense of a school without screens", the problems of digital schools have pedagogical, sanitary, social and environmental aspects (BIHOUIX; MAUVILLY, 2016).

We must not forget about the negative social aspects of distance learning. The ability to communicate, conduct discussions, perceive objective and constructive criticism, and form interpersonal and intersex relationships are basic skills that should be a priority for both analog and digital learning.

Here we can highlight such serious disadvantages of distance learning as social isolation and difficulties with the perception of information.

Distance learning deprives teachers and students of "live" communication as an essential element of social experience transfer. It becomes an artificial obstacle between them,

${ }^{10}$ Available: https://narasputye.ru/archives/4312. Access: 10 dec. 2020.

${ }^{11}$ Available: https://www.telegraph.co. Access: 10 dec. 2020.

${ }^{12}$ Available: http://www.oecd.org. Access: 10 dec. 2020. 
but the personality is formed in the process of socialization, "only the personality can influence the upbringing and development of another person" (USHINSKIY, 2005). Interaction via the Internet can not replace real contacts with peers, it prevents a person from getting personal life experience, which he gets only in the process of live communication. In addition, it can be difficult for elementary school students to hold their attention and learn only through textbooks and a monitor screen.

According to UNESCO Director General Audrey Azoulay: "The scale and speed of educational disruption is unprecedented today and may violate the basic rights of many children to receive education" ${ }^{13}$.

B) Teacher readiness.

The ability of a teacher to provide knowledge in an online format requires skill.

The issue of conducting practical and seminar classes for students remains «open», and no solution has been found to the problem of measuring and validating learning. The development of e-learning courses and other materials is also an urgent issue. There was a problem of increasing workload and lack of time in connection with the distance learning transformation, working hours turned into an irregular one. Due to the lack of a clear methodology for monitoring and evaluating knowledge, teachers have to deal with additional verification almost around the clock. Another problem that universities may face is the lack of regulatory documents for calculating teachers ' remuneration for such work. Now, in many universities, most of the salary is calculated from the classroom load. The problem of information security also causes alarmist moods, especially in connection with the incident related to the leak of several thousand recordings of video calls of the Zoom service, widely used in the educational process, to open access on the network. Although ICTs and digital technologies provide a temporary solution to the current crisis, their use is quite risky. Many people's home computers do not have adequate levels of protection.

2. The Complexity and feasibility of implementing online learning.

It is difficult to see how the concept of lifelong learning will have practical implications for a specific target group - during or after a crisis.

It is advisable to build interaction with students in such a way as to find out their level of understanding. It is also important to organize online courses for employees from experts in the field of training to expand the knowledge of teachers.

${ }^{13}$ Available: https://ioe.hse.ru. Access: 10 dec. 2020.

RPGE- Revista on line de Política e Gestão Educacional, Araraquara, v. 25, n. esp. 1, p. 589-599, mar. $2021 . \quad$ e-ISSN:1519-9029 DOI: https://doi.org/10.22633/rpge.v25iesp.1.14999 
You should also understand the difference in the readiness of the population from large cities with well-developed infrastructure, which is much easier to adapt when switching to online than users from rural areas.

But, in General, distance learning in its own right is not a long-term solution. The COVID-19 crisis sheds light on the need for a new model of education"14. We may soon get a mixed learning experience, a kind of re-imagined educational hybrid that combines the best of the two learning formats.

\section{Technical aspect.}

When conducting online training and developing skills, a technical obstacle is the lack of contingency plans for such a large - scale pandemic at present.

It is obvious that the desire to translate programs online creates problems for evaluation and certification, and formal systems will have to look for compatibility and adaptability of various forms and methods of training.

\section{Employees.}

Ensuring business continuity has led to the transfer of organizations ' work to the online plane wherever possible. Therefore, organizations should take certain actions to continue training and developing their employees / staff during the COVID -19 outbreak.

Already, we need to think about the "new" skills that employers need after COVID-19, in terms of what is needed to get people back to work quickly. They may include short-term courses that focus on practical skills.

Here are a few suggestions (far from exhaustive):

- $\quad$ first, identify new priorities for flexible and distance learning based on existing best practices;

- $\quad$ second, how to address the limitations on the capacity of teachers and trainers and the availability of accessible learning materials;

- third, the search for good forms of public-private partnership in the field of education and training to ensure flexible and distance learning using digital technologies;

- finally, the allocation of resources for this new type of training on an expanded scale, including allocations (mostly financial) to marginalized groups during the crisis. 


\section{Conclusions}

Analyzing the recommendations of the transition of the educational process on distance learning in the world of quarantine, provided by the experts of UNESCO, the Organisation for economic cooperation and development (OECD), the European trade Union Committee for education (ETUCE), the World Bank, and various experts in the field of educational policy, pedagogical and scientific community, you can generate the basic postulates that an adequate response to global crisis regime the transformation of education.

- Public authorities need to focus on developing strategies for rapid implementation of specific measures to support students and teachers throughout the forced break in the educational process.

- Technical and organizational support is needed for people who, for various reasons, do not have the necessary equipment, Internet connection and other online tools that provide access to distance education.

- During this busy period, it is vital that the rights and wages of education workers who are at the forefront of the education system's response to COVID-19 and are under significant pressure are protected;

- Ensuring social equality and inclusiveness, avoiding additional social stratification due to the fact that the most vulnerable students from marginalized groups are disproportionately affected by school closures;

- It is very important to protect the personal information of students and teachers, to prevent or minimize risks arising from interaction in the virtual space, including cyberbullying.

ACKNOWLEDGEMENTS: The work is performed according to the Russian Government Program of Competitive Growth of Kazan Federal University. 


\section{How to reference this article}

MALGANOVA, I. G.; DOKHKILGOVA, D. M.; SARALINOVA, D. S. The transformation of the education system during and post COVID-19. Revista on line de Política e Gestão Educacional, Araraquara, v. 25, n. esp. 1, p. 589-599, mar. 2021. e-ISSN:1519-9029. DOI: https://doi.org/10.22633/rpge.v25iesp.1.14999

Submitted: 06/11/2020

Required revisions: $18 / 01 / 2021$

Approved: $23 / 02 / 221$

Published: 01/03/2021 